11.

Teoría política 

Revista de Derecho

de la Pontificia Universidad Católica de Valparaíso XXXIII (Valparaíso, Chile, ${ }^{\text {do }}$ Semestre de 2009)

[pp. $673-698$ ]

\title{
TWO TRADITIONS OF LIBERTY? \\ CONFRONTING DWORKIN AND HAYEK'S LEGAL AND POLITICAL PHILOSOPHY
}

[“¿Dos Tradiciones Sobre la Libertad? Confrontación de la Filosofía Jurídica y Política de Dworkin y Hayek"]

\author{
José Francisco GarCÍA* \\ Universidad del Desarrollo, Santiago de Chile
}

\begin{abstract}
RESUMEN
Mediante el contraste de las ideas del distinguido erudito jurídico Ronald Dworkin, con aquellas defendidas por Friedrich Hayek, ganador del premio Nobel, sobre la relación entre libertad y desigualdad, liberalismo y democracia, esta publicación revela aspectos claves sobre el prolongado debate entre las llamadas "dos tradiciones de libertad", según formuló Hayek, en un intento por analizar la paradoja que, aunque la rama del liberalismo ha estado históricamente en las manos de aquellos que defienden un enfoque más igualitario en cuanto a los asuntos individuales y colectivos (y a menudo significa sacrificar la libertad por la igualdad), es razonable concordar con Hayek que este hecho histórico en la batalla de las ideas debería ser revisado cuidadosamente. Existen razones de peso que sugieren que Hayek podría estar en
\end{abstract}

\begin{abstract}
Contrasting the ideas of the distinguished legal scholar Ronald Dworkin with those defended by Nobel laureate Friedrich Hayek, in the relation between liberty and equality and liberalism and democracy, this paper unveil key aspects of the long term debate among the so called "two traditions of liberty", as formulated by Hayek, in an intent for analyzing the paradox that, although the brand liberalism has been historically in the hands of those who defend a more egalitarian approach to individual and collective questions (and often implies sacrificing liberty for equality), it is plausible to agree with Hayek that this historical fact in the battle of ideas, should be revisited carefully. Strong reasons suggest that Hayek could be right in his claim that a proper "theory of liberty" has been defended historically
\end{abstract}

* Professor of Constitutional Law at Universidad del Desarrollo. Mailing address: Avenida La Plaza No 700, Las Condes, Santiago, Chile. E-mail: jfgarcia@udd.cl. 
lo correcto en cuanto a su afirmación de que una "teoría de la libertad" adecuada ha sido históricamente defendida no por estos liberales, sino por una tradición de ideas que han tenido que ser disimuladas con otros tipos: conservadoras, libertarias o neoliberales, las cuales han generado confusión y desacuerdo.

Palabras ClaVE: Liberalismo - Liberalismo clásico - Derecho Constitucional - Teoría Política. not by these liberals, but by a tradition of ideas that have had to disguise under other brands: conservatives, libertarians or neo-liberals, generating confusion and misunderstanding.

Keywords: Liberalism - Classic Liberalism - Constitutional Law - Political Theory.

\section{INTRODUCTION}

"The world has never had a good definition of the world liberty, and the American people just now are much in need of one. We all declare for liberty: but in using the same word, we do not mean the same thing [...] Here are two, not only different but incompatible things, called by the same name, liberty". Abraham Lincoln

Hayek would understand precisely Lincoln's skepticism on the different views that arise when trying to elaborate a proper "theory of liberty". This debate that developed consistently in the XVIII century began in two countries, England and France. For Hayek, the first of these had experienced liberty; the second did not. As a result, "we have had to the present day two different traditions in the theory for liberty: one empirical and unsystematic, the other speculative and rationalistic-the first based on an interpretation of tradition and institutions which has spontaneously grown up and were but imperfectly understood, the second aiming at the construction of a utopia, which has often been tried but never successfully"1.

The greatest difference between the two views, Hayek argues, is in their respective ideas "about the role of tradition and the value of all the other products of unconscious growth proceeding throughout the ages. It would hardly be unjust to say that the rationalistic approach is here opposed to almost all that is the distinct product of liberty and that gives liberty its value" 2 .

Hayek's interpretation of the contemporary wrong use of the concept "liberalism" would be due to the confusion of these two traditions that

\footnotetext{
${ }^{1}$ HAYEK, Friedrich, The Constitution of Liberty (Chicago, 1960), p. 54.

${ }^{2}$ HAYEK, Friedrich, cit (n.1), p. 1.
} 
could have started when some British liberals (Whigs) adopted the ideas developed by the French liberalism. This author would agree with us, in considering that the French tradition successfully won over time the battle for the "brand". "Liberalism" as well as "liberals" is worldwide related to the French tradition: and this is egalitarian and rationalistic. This conclusion may seem false for some European countries, but we could agree that it is applicable for the rest of the world, where "British" liberals (in the Hayekian sense) have to disguise as conservatives (as caricaturized by their opponents), or create such concepts as "classic liberals" or, more extravagantly, "libertarians" or "neo-liberals", for trying to twist and stretch each possible synonym and reference of the word liberty.

In the United States, and precisely because of the above mentioned, many intellectuals write about liberalism under the "liberal" brand. Fortunately for Hayek, this kind of liberalism has added since long ago, expressly or implicitly -maybe with the intention of not been confused with neo-liberalism- the word egalitarian, in a way to precise their particular kind of liberalism.

But for those who believe in liberty, is still very hard to see how their opponents, especially when encountered face to face in the battle of ideas, can freely use the words liberty and equality in a complementary way and moreover, use them when describing, defining and defending liberalism. Dworkin's work on liberalism, settle a perfect scenario for, once more, and following Hayek, unveil those aspects of Dworkin's work which, when attempting to reconcile liberty and equality, brings more harm than benefit to the long time defended "theory of liberty".

Because of the above mentioned, the goal of this paper is to raise the question if it is proper to consider liberalism as something that does not consider liberty above of all the other political values, starting with equality. If this is true, we can make the legitimate claim that, although the brand liberalism has been historically (and no doubt that in the future still will be) in the hands of those who properly defend an egalitarian approach to individual and collective questions, conceptually we can still denounce this historical mistake; so that "Liberalism" and "liberals" should be used properly when describing those who consider that liberty is the most important political value.

In this sense, when addressing the questions established by Dworkin, "Do liberty and equality often conflict, as is widely supposed? Must an egalitarian society cheat the liberty of its citizens? Or can the two virtues 
be reconciled, so that we can have all we should anyway want of each?"3, we will observe that the classic liberal tradition, represented by Hayek, gives strong arguments for concluding that this objective-the reconciliation between liberty and equality- is a very difficult task for a coherent "theory of liberty", and when standing in the crossroad between this two concepts, liberty should never be sacrificed under the name of equality.

For achieving our goal we will focus in the specific approaches of Dworkin and Hayek to liberalism, especially in their views of the relation between liberty and equality, and liberty and democracy, that we consider are very good parameters for analizaing the differences among this two liberal traditions that have fought at least for the last three centuries for defining the content of a "theory of liberty". Our analysis will rely mainly in Dworkin's works, in Hayek's Constitution of Liberty; as well as works from other well known legal and political philosophy scholars that critique or support the views of our authors on specific issues, in what we hope can enrich the overall analysis and bring different perspectives to this debate.

\section{DWORKIN'S LIBERALISM}

\section{Liberty and Equality.}

In Sovereign Virtue's Equality of Welfare ${ }^{4}$, the notion of welfare egalitarianism is severly criticized by Dworkin, considering in turn success, conscious state, and objective versions of it. The Dworkinian starting point is to consider two general theories of distributional equality. The first (equality of welfare) holds that a distributional scheme treats people as equals when it distributes or transfers resources among them until no further transfer would leave them more equal in welfare. The second (equality of resources) holds that it treats them as equals when it distributes or transfers so that no further transfer would leave their shares of the total resources more equal.

Three objections are leveled at welfarism so understood by Dworkin in the words of Burley ${ }^{5}$. The first is that there is no one dimension of life that we all value fundamentally and equally. The second is that welfarism is self-defeating: assessment of whether inequalities in the distribution of

\footnotetext{
${ }^{3}$ DwOrkin, Ronald, Sovereign Virtue: The Theory and Practice of Equality (Cambridge, 2000), p. 123.

${ }^{4}$ DwOrkin, Ronald, cit. (n. 3), pp.11-64.

${ }^{5}$ Burley, Justine, Introduction in Burley, Justine (ed.), Dworkin and His Critics (Massachusetts, 2004), p. xiii.
} 
welfare obtain necessarily involves recourse to a theory of fair shares which, being independent of equality of welfare requires the latter's abandonment. Finally, it cannot avoid catering to "expensive tastes". On the basis of this three objections and supporting argumentation, Dworkin concludes that we should have strong reasons to reject welfarist approaches to equality.

In Equality of Resources ${ }^{6}$, Dworkin argues for an alternative conception of equality to that of welfarism-equality of resources. This conception assumes that "equality of resources" is a matter of equality "in whatever resources are owed privately by individuals. Equality of political power $[\ldots]$ is therefore treated as a different issue"

Dworkin thinks that we should prefer his theory to any welfarist conception because it offers relatively robust distributive principles, and is faithful to the liberal notion that individuals should be allowed to decide for themselves, within certain parameters, which aspects of life hold value. In context, the theory may be regarded as the linchpin of a more ambitious project in which Dworkin aims to provide "a unified account of equality and responsibility". Equality of resources promotes an economic structure that is sensitive to individual's choices (or personality) and insensitive to unchosen differences between their mental and physical capacities, including talents levels (personal resources or circumstances).

Two necessary conditions for an equal distribution of resources are freedom from envy and true opportunity costs. To illustrate how a distribution could meet the first condition, Dworkin uses a hypothetical auction. The auction device is complemented by a liberty/constraint system to guarantee the second condition. An ideal equal distribution of resources is said to obtain when, following an auction in which available resources are offered up in the most abstract form possible and in other conditions conductive to authentic preference, no one would prefer any resource bundle successfully bid for by others to their own. This formulation of ideal resource equality takes no account of differences in people's natural endowments?

How might ideal equality be approximated in the light of these? Post auction wealth holdings will become progressively unequal owing both to different choices people have made and to unchosen relative differences in their natural capacities -state of health and levels of talent. Resource egalitarianism does not permit the state to redistribute wealth to mitigate

\footnotetext{
${ }^{6}$ DwOrkin, Ronald, cit. (n.3), pp. 65-119.

${ }^{7}$ Ibíd., p. 65.

${ }^{8}$ Burley, Justine, cit. (n. 5), p. xiv.

${ }^{9}$ Ibíd., p. xiv.
} 
inequalities that are traceable to "personality," that is, to lifestyle choices, preferences, tastes, and so forth, with which an agent identifies (choice). But it does mandate compensation to people whose resource shortfalls are traceable to "brute bad luck" (chance) like genetic-based disease. In a society governed by equality of resources, what an individual is compensated for, and by how much, is modeled on the results of the appropriate hypothetical insurance scheme. There are two principal schemes: one is geared to deal with health-related misfortune, the other with morally relevant differences in talent between individuals. Respectively these schemes are designed to be as sensitive as possible to individual choices about which aspects of health and occupation matters most. Through hypothetical insurance models Dworkin seeks to translate welfarist concerns into the language of money, and to introduce individual responsibility for whether and how measures are taken to alleviate inequalities in wealth that are not traceable to choice. The above discussion informs real world practice with respect to wealth distribution in a variety of ways, including the endorsement of progressive taxation and state-run health insurance. The personality/circumstance distinction drawn by Dworkin in equality of resources circumscribes personal and collective responsibility and is, he tells us, the backbone of our wider ethics and morality ${ }^{10}$.

In his essay The Place of Liberty ${ }^{11}$, Dworkin argues that certain liberal rights are constitutive elements of equality rather than independent considerations that conflict with it. The crux of this view is that a system of baseline rights is required, if market procedures (like the auction) are to legitimize outcomes. When answering the implications for liberty of his claim of equality of resources, Dworkin circumscribes the debate from the starting point: "The question is limited in two ways. First, I mean by liberty what is sometimes called negative liberty-freedom from legal constraint- not freedom or power more generally. Second, I am interested not in liberty generally, but only in the connection between liberty and distributional equality" ${ }^{12}$.

In this sense, the broader claim defended by Dworkin is that "if we accept equality of resources as the best conception of distributional equality, liberty becomes an aspect of equality rather than, as it is often thought to be, an independent political ideal potentially in conflict with it" ${ }^{13}$. Dworkin proposes that the defense of the most important liberties must proceed, not

\footnotetext{
${ }^{10}$ Ibíd., p. xiv.

${ }^{11}$ Dworkin, Ronald, cit. (n. 3), pp. 120-183.

${ }^{12}$ Ibíd., p. 120.

${ }^{13}$ Ibíd., p.121.
} 
by insisting that liberty is more important than equality, "but by showing that these liberties must be protected according to the best view of what distributional equality is, the best view of when a society's distribution of property treats each citizen with equal concern. That claim seems plausible if we accept equality of resources as the best view" ${ }^{14}$.

This formulation is also consistent with his idea of liberalism: "We must reject the simple idea that liberalism consists in a distinctive weighting between constitutive principles of equality and liberty. But our discussion of the idea of equality suggests a more fruitful line. I assume that there is broad agreement within modern politics that the government must treat all its citizens with equal concern and respect"15.

The connection between liberty and equality can also be use to answer what does it mean for the government to treat its citizens as equals. "That is" says Dworkin "the same question as the question of what it means for the government to treat all its citizens as free, or as independent, or with equal dignity [...] It may be answered in two fundamentally different ways. The first supposes that government must be neutral on what might be called the question of the good life. The second supposes that government cannot be neutral on that question, because it cannot treat its citizens as equal human beings without a theory of what humans ought to be"16.

In other words, the first theory of equality supposes that political decisions must be so far as is possible, independent of any particular conception of the good life or of what gives value to life. Since the citizens of a society differ in their conceptions, the government does not treat them as equals if it prefers one conception to another. The second theory argues, on the contrary, that the content of equal treatment cannot be independent of some theory about the good for man or the good of life, because treating a person as an equal means treating him the way the good or truly wise person would wish to be treated. Nevertheless, this last proposition -that the requirement of government neutrality between conceptions of good and bad ways of life is an implication of a true political principle, that everyone is entitled to equal concern and respect- has inspired strong refutations from the natural law perspective, especially from authors like

\footnotetext{
${ }^{14}$ Ibíd.,p. 122.

${ }^{15}$ Dworkin, Ronald, A Matter of Principle (Cambridge, 1985), p. 191.

${ }^{16}$ DwOrKIn, Ronald, cit. (n. 5), p. 191.
} 
Finnis $^{17}$ and George ${ }^{18}$.

\section{Liberalism and Democracy.}

In his renowned book Taking Rights Seriously ${ }^{19}$, Dworkin argues that "citizens are supposed to have certain fundamental rights against their Government, certain moral rights made into legal rights by the Cons-

${ }^{17}$ For Finnis: "To constrain people's actions on the ground that the conception of the good which (if they are done in good faith) those actions put into effect is a bad conception, may manifest not contempt but rather a sense of the equal worth and human dignity of those people; the outlawing of their conduct may be based simply on the judgment that they have seriously misconceived and are engaged in degrading human worth and dignity, including their personal worth and dignity along with that of others who may be induced to share in or emulate their degradation. In no field of human discourse or practice should one equate judging persons mistaken (and acting on that judgment) with despising those persons or preferring those who share one's judgment: FinNis, John, Natural Law and Natural Rights (Oxford, 1980), pp. 221-223. Afterwards Dworkin revised his argument. Equality of concern and respect is violated whenever sacrifices or constraints are imposed on citizens in virtue of an argument they could not accept without abandoning their sense of their equal worth-for 'no self respecting person who believes that a particular way to live is most valuable for him can accept that this way of life is base or degrading': DwORKIN, Ronald, cit. (n.15), p. 206. But this argument is as impotent as its forerunners. To forbid people's preferred conduct does not require them to 'accept and argument'. And if they did accept the argument on which the law is based, they would be accepting that that their former preferences were indeed unworthy of them (or, if they had always recognized that, but had retained their preferences nonetheless, it would amount to an acknowledgment that they had been unconscientious). People can come to regret their previous views and conduct; so one must not identify persons (and their worth as human beings) with their current conception(s) of human good. In sum: either those who preferred conduct is legally proscribed come to accept the concept of human worth on which the law is based, or they do not. If they do, there is no injury to their self respect; they realize that they were in error, and may be glad of the assistance which compulsion let to reform: (Think of drug addicts). And if they do not come to accept the law's view, the law leaves their self-respect unaffected; they will regard the law, rightly or wrongly, as pitiably (and damagingly) mistaken in its conception of what is good for them. They may profoundly recent the law. What they cannot accurately think is that a law motivated by concern for the good, the worth and the dignity of everyone without exception, does not treat them as an equal. FInNIs, John, Kant v. Neo-Kantians, in Columbia Law Review 87 (1987), pp. 437-438. Also see FinNis, John, Is Natural Law Theory Compatible with Limited Government? in GEORGE, Robert (ed.), Natural Law, Liberalism and Morality (Oxford, 2002), pp. 1-26.

${ }^{18}$ George, Robert, Making Men Moral: Civil Liberties and Public Morality (Oxford, 1993).

${ }^{19}$ Dworkin, Ronald, Taking Rights Seriously (Cambridge, 1977), pp.184-205. 
titution [...]. But those Constitutional rights that we call fundamental like the right of free speech, are supposed to represent rights against the Government in the strong sense; that is the point of the boast that our legal system respects the fundamental rights of the citizens" ${ }^{20}$. He added: "It is true that we speak of the 'right' of society to do what it wants, but this cannot be a 'competing right' of the sort that may justify the invasion of a right against the Government" ${ }^{21}$. The existence of rights against the Government, argues Dworkin, would be jeopardized if the Government were able to defeat such a right by appealing to the right of a democratic majority to work its will: "A right against the Government must be a right to do something even when the majority thinks it would be wrong to do it, and even when the majority would be worse off for having it done"22. Moreover, "if we now say that society has a right to do whatever is in the general benefit or the right to preserve whatever sort of environment the majority wishes to live in, and we mean that these are the sort of rights that provide justification for overruling any rights against the Government that may conflict, then we have annihilated the rights. In order to save them, we must recognize as competing rights only the rights of other members of the society as individuals"23.

In this sense, Dworkin's proposition is that we should distinguish the 'rights' of the majority as such (which cannot count as a justification for overruling individual rights), and the personal rights of members of a majority. This tension between liberalism and democracy, especially when considering individual rights against the rights of the majority, will be developed later in his essay Liberalism ${ }^{24}$.

In Liberalism, Dworkin address this question starting from the contractarian perspective, where a liberal is asked to found a new state. The liberal is required to dictate its constitution and fundamental institutions. $\mathrm{He}$ must propose a general theory of political distribution, that is "a theory of how whatever the community has to assign, by way of goods or resources or opportunities, should be assigned [...] He will decide that there are no better mechanisms available, as general political institutions than the two main institutions of our own political economy: the economic market, for decisions about what goods shall be produced and how they shall be distributed, and representative democracy, for collective decisions about

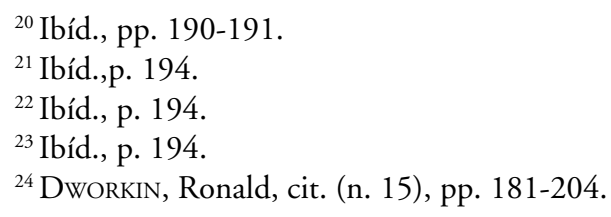


what conduct shall be prohibited or regulated so that other conduct might be made possible or convenient" ${ }^{\prime 25}$.

Thus, for Dworkin, the liberal lawgiver therefore faces a difficult task: his conception of equality requires an economic system that produces certain inequalities (those that reflect the true differential costs of goods and opportunities) but not others (those that follow from differences in ability, inheritance, and so on). The market produces both the required and the forbidden inequalities, and there is no alternative system that can be relied upon to produce the former without the latter. Because of this, "the liberal must be tempted, therefore, to a reform of the market through a scheme of redistribution that leaves its pricing system relatively intact but sharply limits, at least, the inequalities in welfare that his initial principle prohibits. No solution will seem perfect. The liberal may find the best answer in a scheme of welfare rights financed through redistributive income and inheritance taxes of the conventional sort, which redistributes just to the Rawlsian point, that is, to the point at which the worst-off group would be harmed rather than benefited by further transfers" ${ }^{26}$.

The dworkinian liberal lawgiver must now consider the second of the two familiar institutions: representative democracy. In effect, democracy is justified because "it enforces the right of each person to respect and concern as an individual; but in practice the decisions of a democratic majority may often violate that right, according to the liberal theory of what the right requires" 27 .

So the liberal drawn to the economic market and to political democracy for distinctly egalitarian reasons, finds that these institutions will produce inegalitarian results unless he adds to his scheme different sorts of individual rights: "These rights will function as trump cards held by individuals; they will enable individuals to resist particular decisions in spite of de fact that these decisions are or would be reached through the normal workings of general institutions that are not themselves challenged"28. In effect, the ultimate justification for these rights is that they are necessary to protect equal concern and respect; but they are not to be understood as representing equality in contrast to some other goal or principle served by democracy or the economic market. For Dworkin, the "familiar" idea that rights of redistribution are justified by an ideal of equality that overrides the efficiency ideals of the market in certain cases,

\footnotetext{
${ }^{25}$ Ibíd., pp. 192-194.

${ }^{26}$ Ibíd., pp.195-196.

${ }^{27}$ Ibíd., p. 196.

${ }^{28}$ Ibíd., p. 198.
} 
has no place in liberal theory: "For the liberal, rights are justified not by some principle in competition with an independent justification of the political and economic institutions they qualify, but in order to make more perfect the only justification on which these other institutions may themselves rely. If the liberal arguments for a particular right are sound, then the right is an unqualified improvement in political morality, not a necessary but regrettable compromise of some other independent goal, like economic efficiency"29.

In Political Judges and the Rule of Law ${ }^{30}$, Dworkin argues that it would be a nice question to answer whether any particular individual gains in power more than the loses, when courts undertake to decide what political rights an individual has. "Access to courts may be expensive, so that the right of access is in that way more valuable to the rich than to the poor. But since, all else equal, the rich have more power over the legislature than the poor, at least in the long run, transferring some decisions from the legislature may for that reason be more valuable to the poor. Members of entrenched minorities have in theory most to gain from the transfer, for the majoritarian bias of the legislature works harshly against them, and it is their rights that are for that reason most likely to be ignored in that forum" 31 .

Dworkin analysis seems to give Courts a key role in this discussion. In this sense, if courts take the protection of individual rights as their special responsibility, then minorities will gain in political power to the extent that access to the courts is in fact available to them, and to the extent to which the courts' decisions about their rights are in fact sound. The gain to minorities, under these conditions, would be greatest under a system of judicial review of legislative decisions. This analysis is severely criticized by Ackerman ${ }^{32}$.

Ackerman includes Dworkin in what he calls the "Rights Foundationalists" school, in which very different authors like Epstein, Fiss and Dworkin himself would agree in that "Whatever rights are Right [...] the American Constitution is concerned, first and foremost, with their protection" 33 . "Indeed", Ackerman continues, "the whole point of having rights is to trump decisions rendered by democratic institutions that may otherwise

\footnotetext{
${ }^{29}$ Ibíd., p. 198.

${ }^{30}$ Ibíd.,pp. 9-32.

${ }^{31}$ Ibíd., pp. 27-28.

${ }^{32}$ Ackerman, Bruce, We The People, I: Foundations (Cambridge, 1991).

${ }^{33}$ Ibíd., p. 11.
} 
legislate for the collective welfare" 34 . In this sense, "rights foundationalism" sees the task of constitutional theorizing as that of identifying principles worthy of preempting democratic choice. To this extend, Dworkin tries monist-like (doctrinaire democrats in the Hayekian sense) to dissolve the tension with democracy by arguing that "the American conception of democracy is whatever form of government the Constitution, according to the best interpretation of that document establishes" 35 . For Ackerman, while none of these "right foundationalist" theorists completely denies a place for democratic principles, their populist enthusiasms are constrained by deeper commitments to fundamental rights ${ }^{36}$.

${ }^{34}$ Ibíd., p. 11.

${ }^{35}$ Dworkin, Ronald, Unenumerated Rights: Whether and How Roe Should Be Overruled, in The University of Chicago Law Review 59 (1992), p. 385. The impact of this discussion for Posner is particularly relevant: "Since the Constitution implicitly authorizes judicial review of the validity of legislation, such review cannot be antidemocratic - nothing allowed by the Constitution can be. This is a conversation stopper all right. It disables us from saying not only that Athens was more (or less) democratic than modern America, but also that America would be more democratic if judges were less willing than they are to invalidate legislation.” POSNER, Richard, Overcoming Law (Cambridge, 1995), p. 216.

${ }^{36}$ In fact, that the Supreme Court may invalidate statutes in the name of fundamental rights, is seemed by some authors as a "countermajoritarian difficulty"that renders judicial review presumptively illegitimate. However, for Ackerman, this "difficulty" does not seem so formidable to the foundationalist: "Instead, she is more impressed by the fact that a democratic legislature might endorse and number of oppressive actions-establish a religion, or authorize torture, or [...] When such violations occur, the foundationalist demands judicial intervention despite the breach of democratic principle. Rights trump democracy-provided, of course, that they're the Right rights": ACKERMAN, Bruce, cit. (n. 32), pp. 11-12. Nevertheless, Ackerman thinks this is precisely the difficulty: the arbitrariness of the foundationalist discourse when defining rights-recurring to philosophers like Kant and Locke in an effort to understand the Constitution. Ackerman response is a dualist theory of democracy, in which the establishment of constitutional rights is also a democratic decision, although a decision that implies stringent requirements than the one provided by an occasional parliamentarian majority. This "higher level" democratic decisions are denominate by Ackerman "popular decisions" or from "We the people". In this sense, a dualist Constitution seeks to distinguish between two different decisions that may be made in a democracy. The first is a decision by the American people; the second, by their government. "Decisions by the People occur rarely, and under special constitutional conditions. Before gaining the authority to make supreme law in the name of the People, a movement's political partisans must, first, convince an extraordinary number of their fellow citizens to take their proposed initiative with a seriousness that they do not normally accord to politics; second, they must allow their opponents a fair opportunity to organize their own forces; third, they must convince a majority of their fellow Americans to support their initiative as its merits are discussed, time 
Both Dworkin and Ackerman's positions are criticized by Posner ${ }^{37}$. For Posner, Dworkin believes that only his approach can prevent constitutional doctrine from changing with every change in the composition of the Court. "This belief, another example of the intellectualist fallacy, exaggerates both the possibility of cogent theorizing at the high level of abstraction implied by the holistic approach, and the fidelity of judges, especially Supreme Court Justices, whose decisions are unreviewable to the doctrines (as distinct from narrow holdings) of their predecessors. Nothing but force majeure can prevent judges from giving vent to their political and personal values, if that is what they want to do. They may not want to, if they are thoroughly imbued with the old fashioned formalist virtues of stare decisis and strict construction. But of course Dworkin does not want that. He approves of Brown, and Griswold, and Roe. He wants to package novelty as orthodoxy" ${ }^{\prime 3}$. Posner's conclusion is fatal for Dworkin's claim: "As Dworkin would say, the question posed by an originalist versus an activist or a pragmatic judiciary is not one of democracy or no democracy, but one of the kind of democracy we want" ${ }^{\prime \prime}$.

\section{HAYEK'S LIBERALISM}

Do liberty and equality often conflict, as is widely supposed? Must an egalitarian society cheat the liberty of its citizens? Or can the two virtues be reconciled, so that we can have all we should anyway want of each? ${ }^{40}$. Having seen Dworkin's position on the relation of liberty and equality and liberalism and democracy, we will now proceed to Hayek's views on

and again, in the deliberative for a provided for "higher lawmaking." It is only then that a political movement earns the enhanced legitimacy the dualist Constitution accords to decisions made by the people": ACKERMAN, Bruce, cit. (n. 32), p. 6. Thus conceived Dualism, "the basic mediating device is a two track system of democratic lawmaking. It allows an important place for the foundationalist's view of 'rights as trumps' without violating the monist's (a traditional democrat) deeper commitment to the primary of democracy": ACKERMAN, Bruce, cit. (n. 32), p. 12.

${ }^{37}$ Posner, Richard, cit. (n. 35). His critique on Ackerman's We the People can be found in pp. 215-228, and in PosNer, Richard, Frontiers of Legal Theory (Cambridge, 2001), pp. 170-192. Posner also argues that we should consider that "Dworkin is no 'originalist,' in the sense of someone who believes that modern constitutional issues should be decided by reference to the meanings that the words of the Constitution bore in the eighteen century or to the mental horizons of the framers": Posner, Richard, cit. (n. 37), p.155.

${ }^{38}$ Posner, Richard, cit. (n. 35), p. 194.

${ }^{39}$ Ibíd.

${ }^{40}$ DwOrkin, Richard, cit. (n. 3), p.123. 
the matter. For us, Hayek is a "representative agent" of the classic liberal tradition, and more specifically have analyzed deeply the differences between this two "traditions" of liberalism, stating that the one that focus primarily in trying to reconcile liberty with equality, can not be seen as an authentic representative of a proper "theory of liberty".

\section{Liberty and Equality.}

In The Constitution of Liberty, Hayek affirmed that: "The state in which a man is not subject to coercion by the arbitrary will of another or other is often distinguished as 'individual' or 'personal' freedom" ${ }^{41}$. This formulation of freedom is better known as Isaiah Berlin's negative liberty ${ }^{42}$, which is centered in the concept of freedom as absence from coercion ${ }^{43}$, which demands a negative behavior both from private individuals as well as Government ${ }^{44}$. Under this formulation, individuals are left free for following their own will, pursuing those ends and objectives that are freely chosen by them, which includes the liberty for defining the most effective and efficient means for accomplishing it. In other words, "it meant always the possibility of a person's acting according to his own decisions and plans, in contrast to the position of one who was irrevocably subject to the will of another, who by arbitrary decision could coerce him to act or not to act in specific ways" 45 .

Thus, freedom refers solely to a relation of men to other men, and the only infringement on it is coercion by men. For Hayek, this means, in particular, "that the range of physical possibilities from which a person can choose at a given moment has no direct relevance to freedom [...] Whether he is free or not does not depend on the range of choice but on whether he can expect to shape his course of action in accordance with his present intentions, or whether somebody else has power so to manipulate

${ }^{41}$ HaYeK, Friedrich, cit. (n.1), p. 11.

${ }^{42}$ Berlin, Isaiah, Four Essays on Liberty (Oxford, 1969), p. 128. An excellent analysis of this two types of liberty in Berlin's thought can be found in GraY, John, Isaiah Berlin (Princeton, 1996). However, Hayek himself attributes to T.H. Green the popularization of the distinction between "positive" and "negative" liberty, and through him derives ultimately from Hegel.

${ }^{43}$ Coercion, is understood by Hayek, as "such control of the environment or circumstances of a person by another that, in order to avoid greater evil, he is forced to act not according to a coherent plan of his own but to serve the ends of another". HAYEK, Friedrich, cit. (n. 1), pp. 20-21.

${ }^{44}$ In this case Government must behave in a positive (active) way: guarantee that individuals are free from other individual's coercion.

${ }^{45}$ HAYEK, Friedrich, cit. (n. 1), p. 12. 
the conditions as to make him act according to that person's will rather than his own" ${ }^{46}$.

Thus, liberty presupposes that a private sphere is assured to individuals, that there is some set of circumstances in the environment that surrounds him that cannot be violated or interfered by others. In other words, coercion is evil precisely because it thus eliminates an individual as a person and transforms him a mere tool in the achievement of the goals of other individuals.

However, is fundamental that we state to this point that coercion can not be completely avoided because the only way to prevent it is by the threat of coercion. In effect: "Free society has met this problem by conferring the monopoly of coercion on the state and by attempting to limit this power of the state to instances where it is required to prevent coercion by private persons" ${ }^{\prime \prime}$. This is possible, for Hayek, only by the state's protecting known private spheres of the individuals against interference by others and delimiting theses private spheres, not by specific assignation, but by creating conditions under which the individual can determine his own sphere by relying on rules which tell him what the government will do in different types of situations.

Hayek thinks that it is crucial that we properly differentiate this concept of freedom with others that historically had help to confuse things.

In this sense, the first meaning of freedom with which we must contrast with the Hayekian formulation -freedom as absence from coercion- is with political freedom, understood as "the participation of men in the choice of their government, in the process of legislation, and in the control of administration" ${ }^{38}$. Under this formulation, freedom (intrinsically individual) is understood as a collective concept. This could be interpreted, absurdly in our view, as the fact that individuals must participate in this collective freedom for been able to be free individually considered. This seems not only totalitarian, but makes us consider the way that democracy per se is able (or unable) to guarantee individuals freedom. In this sense, Hayek states that: "the fact we have seen millions voting themselves into complete dependence on a tyrant has made our generation understand that to choose one's government is not necessarily to secure freedom" ${ }^{49}$.

Secondly, we can not confuse "inner", "metaphysical" or "subjective" freedom with the Hayekian version of freedom. The first refers to the

\footnotetext{
${ }^{46}$ Ibíd., p. 13.

${ }^{47}$ Ibíd., p. 21.

${ }^{48}$ Ibíd., p. 13.

${ }^{49}$ Ibíd., p. 14.
} 
extent to which "a person is guided in his actions by his own considered will, by his reason or lasting conviction, rather than by momentary impulse of circumstance" 50 . In this sense the opposite of "inner" freedom in not coercion by others, "but the influence of temporary emotions, or moral or intellectual weakness"51. Thus, whether or not a person is able to choose wisely between options, or to adhere to a choice she has made, is a problem distinct from whether or not other people will impose their will upon her.

A third concept of freedom-and in Hayek's view, the most dangerous of the possible confusions when comparing among the different meanings of freedom- is the understanding of freedom as "the physical 'ability to do what I want,' the power to satisfy our wishes, or the extent of the choice of alternatives open to us" 52 . Once this identification of freedom with power is admitted, continues Hayek, "there is no limit to the sophisms by which the attractions of the word 'liberty' can be used to support measures which destroy individual liberty, no end to the tricks by which people can be exhorted in the name of liberty to give up their liberty. It has been with the help of this equivocation that the notion of collective power over circumstances has been substituted for that of individual liberty and that in totalitarian states liberty has been suppressed in the name of liberty" ${ }^{33}$.

Berlin talks about positive liberty for describing the concept of freedom as power, which we can understand also as auto-determination, auto-possession and auto-dominium. In the political sphere, collective regimes (such as Marxists), has commonly invoked this notion of freedom (positive) as liberation from hunger or class exploitation, ending in the establishment of profoundly illiberal and repressive societies, that demand that is assured to individuals the effective access to basic economic goods, which is the basis for exercising the rest of the freedom $s^{54}$.

Hayek's description tries to avoid the suggestion that the use of freedom in these different notions, simply means that these are different species of the same category. For Hayek "this is the source of dangerous nonsense, a verbal trap that leads to the must absurd conclusions. Liberty in the sense of power, political liberty, and inner liberty are not states of the same kind as individual liberty: we cannot, by sacrificing a little of

\footnotetext{
${ }^{50}$ Ibíd., p. 15.

${ }^{51}$ Ibíd., p. 15.

${ }^{52}$ Ibíd., p. 16.

${ }^{53}$ Ibíd., p. 16.

${ }^{54}$ Berlin, Isaiah, cit. (n. 47).
} 
the one in order to get more of the other, on balance gain some common element of freedom" 55 .

For Hayek the great aim of the struggle for liberty has been equality before the law. For the author this is the only way that we can reconcile liberty and equality. In effect, equality of the general rules of law and conduct "is the only kind of equality conducive to liberty and the only equality which we can secure without destroying liberty. Not only has liberty nothing to do with any other sort of equality, but it is even bound to produce inequality in many respects. This is the necessary result and part of the justification of individual liberty: if the result of individual liberty did not demonstrate that some manners of living are most successful than others, much of the case for it would vanish" ${ }^{56}$. He added: "From the fact that people are very different it follows that, if we treat them equally, the result must be inequality in their actual position, and that the only way to place them in an equal position would be to treat them differently"57. Thus, for Hayek, equality before the law and material equality are therefore not only different but are in conflict with each other: "we can achieve either the one or the other, but not both at the same time" 58 . The equality before the law which the Hayekian version of freedom requires leads necessarily to material inequality. In this sense, Hayek's argument implies that, though where the state must use coercion for other reasons, it should treat all people alike, the desire of making people more alike in their condition cannot be accepted in a free society as a justification for further and discriminatory coercion.

Hayek's position is not an objection to equality as such, "it merely happens to be the case that a demand for equality is the professed motive of most of those who desire to impose upon society a preconceived pattern of distribution" 59 . His argument implicitly acknowledges that we cannot know enough about each person's situation to distribute to each according to his moral merit; and he goes on to say, "Our objection is against all attempts to impress upon society a deliberately chosen pattern of distribution, whether it be an order of equality or of inequality. We shall indeed see that many of those who demand an extension of equality do not really demand equality but a distribution that conforms more closely to human

\footnotetext{
${ }^{55}$ HayeK, Friedrich, cit. (n. 1), p. 18.

${ }^{56}$ Ibíd., p. 85.

${ }^{57}$ Ibíd., p. 87.

${ }^{58}$ Ibíd., p. 87.

${ }^{59}$ Ibíd., p. 87.
} 
conceptions of individual merit and that their desires are as irreconcilable with freedom as the more strictly egalitarian demands" 60 .

Under Hayek's formulation, distribution in a free society will be in accordance with value rather than moral merit; that is, in accordance with the perceived value of a person's actions and services to others: "in a free system it is neither desirable not practicable that material rewards should be made generally to correspond to what men recognize as merit and that is an essential characteristic of a free society that an individual's position should not necessarily depend on the views that his fellows hold about the merit he has acquired" 61 . For Hayek, the term "merit" is used exclusively to describe the attributes of conduct that make it deserving of praise, that is, "the moral character of the action and not the value of the achievement" 62 . Thus, reward according to merit must in practice mean reward according to assessable merit, merit that other people can recognize and agree upon.

Hayek's final statement of his argument is that the prizes that a free society offers for the result serve to tell those who strive for them how much effort they are worth. However, the same prizes will go to all those who produce the same result, regardless of effort. In effect, "What is true here of the remuneration for the same services rendered by different people is even more true of the relative remuneration for different services requiring different gifts and capacities: they will have little relation to merit. The market will generally offer for services of any kind the value they will have for those who benefit from them; but it will rarely be known whether it was necessary to offer so much in order to obtain these services, and often, no doubt, the community could have had them for much less"63.

A society in which the position of the individuals was made to correspond to human ideas of moral merit would therefore be the exact opposite of a free society. For Hayek "It would be a society in which people were rewarded for duty performed instead of for success, in which every move of every individual was guided by what other people thought he ought to do, and in which the individual was thus relieved of the responsibility and the risk of decision" 64 .

For Nozick: "despite his rejection of a patterned conception of distributive justice, Hayek himself suggests a pattern he thinks justifiable:

\footnotetext{
${ }^{60}$ Ibíd., p. 87.

${ }^{61}$ Ibíd., p. 94.

${ }^{62}$ Ibíd., p. 94.

${ }^{63}$ Ibíd., p. 96.

${ }^{64}$ Ibíd., p. 97.
} 
distribution in accordance with the perceived benefits given to others, leaving room for the complaint that a free society does not realize exactly this pattern. Stating this patterned strand of a free capitalist society more precisely we get 'to each according to how much he benefits others who have the resources for benefiting those who benefit them.' This will seem arbitrary unless some acceptable initial set of holdings is specified, or unless it is held that the operation of the system over time washes out any significant effects from the initial set of holdings" ${ }^{\prime}$.

\section{Liberalism and Democracy.}

For Hayek the point where classic liberalism and the democratic movement meet is where, "Equality before the law leads to the demand that all men should have the same share in making the law" ${ }^{66}$. However, there is a constant tension between them that can be founded in the very essence of their goals and concerns $s^{67}$ : "Liberalism [...] is concerned mainly with limiting the coercive powers of all government, whether democratic or not, whereas the dogmatic democrat knows only one limit to governmentcurrent majority opinion [...] Liberalism is a doctrine about what the law ought to be, democracy a doctrine about the manner of determining what will be the law. Liberalism regards it as desirable that only what the majority accepts should in fact be law, but it does not believe that this is

${ }^{65}$ Nozick, Robert, Anarchy, State and Utopia (New York, 1974), p. 158.

${ }^{66}$ HAYeK, Friedrich, cit. (n. 1), p. 103.

${ }^{67}$ For Posner "Liberalism is in tension with democracy. Democracy is a means not only of dispersing political power and thus of protecting the private sphere against invasion by the public sphere, but also of enabling people to enforce their dislike of other people's self regarding behavior. Liberalism implies the limited state, but democracy implies majority rule -and majorities are often willing to coerce minorities. Yet democracy and liberalism support as well as oppose to each other. By placing government under popular control, democracy reduces the power of the state to infringe liberty; and liberty is a precondition of informed and uncoerced, and hence authentic, democratic choice. But liberty in period $t$ can lead to a popular government at period $t+1$ that may decide to immiserate an unpopular minority [...] Recognizing the tension between liberalism and democracy, liberals want to limit the scope of democratic politics through separation of powers and judicial review of executive and legislative actions": See POSNER, Richard, cit. (n. 35), pp. 25-26. Some modern defenders of democracy, like Sunstein, try to bridge the gap between it and liberalism by arguing that voters should never allow themselves to vote selfishly or emotionally, or in a word illiberally. Their votes should always be the result of informed and disinterested deliberation, and if they are, democracy will produce wise and just solutions to social problems: Sunstein, Cass, Democracy and The Problem of Free Speech (New York, 1993), pp. 241-252. 
therefore necessarily good law [...] To the doctrinaire democrat the fact that the majority wants something is sufficient ground for regarding it as good; for him the will of the majority determines not only what is law but what is good law" 68 .

In this sense, the democratic and the liberal traditions thus agree that whenever state action is required, and particularly whenever coercive rules have to be laid down, the decision ought to be made by the majority. However, for Hayek, they differ on the scope of the state action that is to be guided by democratic decision. "While the dogmatic democrat regards it as desirable that as many issues as possible be decided by majority vote, the liberal believes that there are definite limits to the range of questions which should be decided [...] The crucial conception of the doctrinaire democrat is that of popular sovereignty. This means to him that majority rule is unlimited and illimitable.

The ideal of democracy, originally intended to prevent all arbitrary power, thus becomes the justification for a new arbitrary power" ${ }^{\circ 9}$.

If democracy is a means rather than an end, its limits must be determined in the light of the purpose we want it to serve. Hayek states that there are three chief arguments by which democracy can be justified, each of which may be regarded as conclusive.

The first one relies on the idea that democracy is the best method yet discovered for achieving peaceful change. In effect, "whenever it is necessary that one of several conflicting opinions should prevail and when one would have to be made to prevail by force if need be, it is less wasteful to determine which has the stronger support by counting numbers than by fighting" 70 .

The second argument establishes that democracy can be considered as an important mechanism for guaranteeing individual liberty. "This view recognizes, of course," says Hayek "that democracy is not yet liberty; it contends only that it is more likely than other forms of government to produce liberty" 71 .

Finally, and the most powerful argument for Hayek, rests on the effect which the existence of democratic institutions will have on the general level of understanding public affairs. "It is the burden of Tocqueville's great work, Democracy in America, that democracy is the only effective method of educating the majority [...] Democracy is, above all, a process of forming

\footnotetext{
${ }^{68}$ HAYEK, Friedrich, cit. (n. 1), pp. 103-104.

${ }^{69}$ Ibíd., p. 106.

${ }^{70}$ Ibíd., p. 106.

${ }^{71}$ Ibíd., p. 106.
} 
opinion. Its chief advantage lies not in its method of selecting those who govern but in the fact that, because a great part of the population takes an active part in the formation of opinion, a correspondingly wide range of persons is available from which to select" ${ }^{\prime 2}$.

\section{LIBERTY AND EQUALITY: A DIFFICULT RECONCILIATION}

Too many questions arise when we analyze Dworkin's main works in light of a coherent theory of liberalism. But even when we consider some of his specific essays on liberty and equality these questions remain unsolved. In Do Liberal Values Conflict ${ }^{3}$ and Do Liberty and Equality Conflict? $?^{74}$. Dworkin adopts a defensive position, maybe realizing that he puts himself in a very difficult position: the reconciliation of liberty and equality for shaping a coherent "theory of liberty". We could not imagine worse examples for trying to reconcile both values: minimum wage laws or progressive taxes. Hayek's response seems devastating.

In Do Liberty and Equality Conflict? Dworkin first tries to avoid the ideological implications of the discussion. He critiques both conservatives and liberals for trying to invent or create "artificial" meanings for liberty and equality, accusing them of trying to interpret both concepts in a way that put them in a permanent contradiction with one another. But these ideological implications have been in the political debate since long ago, and have contributed to shape the political discourses and policies of both left and right. In this sense, trying to avoid the distinction that has separate left and right since the French revolution is not necessary for addressing these questions. Moreover, is important that society can differentiate its representatives on such an important issue as how much equality (or how much inequality) is society going to tolerate. The meaning and value of this distinction was stated clearly by Bobbio ${ }^{75}$.

But there is a much more serious critique that we could make: Dworkin's reluctance of trying to shape a theory about liberalism that emerges from the plain or flat meaning of liberty and value. Maybe Hayek

${ }^{72}$ Ibíd., p. 108.

${ }^{73}$ Dworkin, Ronald, Do Liberal Values Conflict? in Lilla, Mark - Dworkin, Ronald - Silvers, Robert (eds.), The Legacy of Isaiah Berlin (New York, 2001), pp. 73-90.

${ }^{74}$ Dworkin, Ronald, Do Liberty and Equality Conflict, in Barker, Paul (ed.), Living as Equals (Oxford, 1996), pp. 39-58.

${ }^{75}$ Bоввіо, Norberto, Left and Right: The significance of a Political Distinction (Chicago, 1997). See especially the chapter "Equality and Inequality", pp. 60-71. 
is more modest in this way: he drew the distinction between equality and liberty, and then construed a theory of liberalism based in the negative sense of liberty. But Dworkin, in his permanent effort of setting a new stage for addressing this discussion, caught himself in the worse trap: he recognizes that he is unable to define liberty by its own merit and needs to define it necessarily in relation to his previous concept or definition of equality ${ }^{76}$.

This "circularity" problem has been well developed by recent literature, especially when analyzing the role of freedom in a distributive justice theory ${ }^{77}$. For Carter "[...] we ought to take an interest in how free people are in a literal sense, rather than in a sense that is merely elliptical for how valuable their particular freedoms are in terms of the interests (other than freedom) that they serve. This conclusion has an important implication for the role of freedom in a liberal theory of distributive justice. It implies that a liberal theory of distributive justice must be 'freedom-based' where, by a freedom-based theory of distributive justice', is meant a theory of justice that has something to say about the societal distribution of freedom; that freedom should be maximal, equal, above a certain minimum for all, or whatever"78.

In this sense, Carter is not saying that freedom is the only object of justice; a freedom-based theory of justice need not be based only on the ideal of freedom, but it must be based on that ideal among others. Moreover, Dworkin appears to employ not a freedom-based theory of justice but a justice-definition of freedom. The conclusion in inevitable: "Justice consists in treating individuals with equal concern and respect, and freedom consists in the power to do what one is able to do in an ideally egalitarian society" 79 .

Dworkin's intent of setting the field is unveiled: "Dworkin distinguishes between the empirical, of 'flat', meaning of liberty and its 'normative' meaning (i.e., the definition in terms of equality) and holds that when we say liberty has been sacrificed for equality, we really mean only liberty in the uninteresting flat sense, and that we do not thereby imply that any 'defensible ideal of liberty' has been compromised. In fact, exactly the reverse is true. Liberty does not have to be liberty in Dworkin's 'normative'

${ }^{76}$ Dworkin, Ronald, cit. (n. 73).

${ }^{77}$ CARTER, Ian, The Independent Value of Freedom in Ethics 105 (1995); and OTSUKA, Michael, Liberty, Equality, Envy and Abstraction, in Burley, Justine (ed.), cit. (n. 5), pp. 70-78.

${ }^{78}$ Ibíd., p. 843 .

${ }^{79}$ Ibíd., p. 843. 
sense in order to represent an ideal. On the contrary, to be interested only in liberty in Dworkin's normative sense is to imply that there is no such thing as a defensible ideal of liberty. It is to deny, rather than to affirm, that liberty has a 'distinct quality and value'. Any defense of an ideal which involves defining freedom in terms of that ideal is not; whatever it's others strengths, a defense by appeal to freedom. It is only by taking an interest in liberty in its empirical, flat, 'uninteresting' sense that we are able to accord liberty a distinct quality and value" ${ }^{80}$.

From another perspective, Otsuka begins by challenging Dworkin's presupposition of the compossibility of the envy test and the realization of the principle of abstraction. Necessary to Dworkin's account of ideal equality is a maximally sensitive liberty/constraint system, which he derives from the "principle of abstraction." According to this principle, resources in the initial auction must be offered in as abstract a form as possible to afford the greatest flexibility possible in the matching of bids to plans and preferences. Otsuka notes that the abstraction principle condemns any laws constraining gift-giving. This is a problem, because the bestowal of gifts frustrates the envy test by allowing some recipients to become wealthier than others. Moreover, Dworkin's proposal that gifts should be regulated by a tax modeled on hypothetical insurance does not wholly avoid frustration of the envy test. Furthermore, and importantly, Dworkin's more recent response to the problem undermines his reconciliation project. Dworkin now thinks that two competing egalitarian demands are relevant to gift-giving: the first is provided by the envy test, the second by the principle of abstraction. Otsuka argues that that this compromise between the envy test and the principle of abstraction prevents the reconciliation of the two values of liberty and equality. All Dworkin's "reconciliation" amounts to is "a demonstration that the conflict between liberty and equality is a competition intermixed with cooperation, which takes place wholly within the boundaries of distributive equality, rather than a conflict between equality and the external demand of liberty." ${ }^{11}$

For Hayek, the conflict among liberty and equality is not artificial but permanent. His theory of liberty (or liberalism) does not admit more equality that equality under the law. Any other intent of Government to equalize things among individuals necessarily will imply less liberty. Moreover, Hayek would have argued that Dworkin's “constructivist auction" was born to fail anyway (for Dworkin's purposes, because for

\footnotetext{
${ }^{80}$ Ibíd., pp. 843-844.

${ }^{81}$ Ibíd., p. 845 .
} 
Hayek it would simply mean that the market will do its job), and that the corrections proposed by Dworkin (insurance system for helping the less talented individuals and the unlucky ones) would imply an unacceptable discretion and intervention of the Government in areas that can not handle (especially because of lack of information, one of the most important contributions of Hayek to economics) .

Finally, when confronted with the tension between liberalism and democracy we still see clear differences among the authors. Although Dworkin's approval of such a controversial mechanism for "doctrinaire" democrats like the judicial review could be seen as a classical liberal position, in the sense of establishing constitutional mechanisms that can protect the rights of minorities against the tyranny of occasional majorities; his vision of democracy is still different. We could reasonable argue that Dworkin position is that is a good thing to have judicial review, but we still need democracy for correcting those areas and questions that the market can not. In this sense, Dworkin's incoherence is again unveiled: from one hand, the political process is permitted to redistribute rights among individuals, and from the other, we establish the judicial review precisely for trying to guarantee constitutional rights (a safeguard from the political process).

In contrast, Hayek sees democracy in a much more instrumental way: he does not only firmly estates the "cliche" that democracy is a mean not an end (with all that implies this affirmation), but finds that is a good mechanism for the distribution of power, preserving the liberty (more than any other mechanism or system of government yet invented by men) and can serve as a filter for selecting statesman: maybe not the wiser, but at least a sufficient number of candidates that prevents from having the worse.

\section{CONCLUSIONS}

When confronting the notions and definitions related to what we have called a "theory of liberty" between two of the greatest intellectuals of the last part of the XXth century, Ronald Dworkin and Friedrich Hayek, paradoxically, both try to defend the same thing reaching different results. Because of this, it seems legitimate to explore these differences and try to find if it is possible to solve the dispute among the "two traditions of liberty", as formulated by Hayek.

When analyzing the Hayekian view on liberty, equality and democracy, we find not only significant differences with Dworkin, but above all, we find strong arguments for concluding that Dworkin's reconciliation 
between liberty and equality is not only a very difficult task for a coherent "theory of liberty", but when standing in the crossroad between this two concepts, it seems that liberty can never be sacrificed under the name of equality. Also, democratic values can never be an excuse for the infringement of individual liberties, and in this sense, it is still a noble effort to defend, as Hayek and the classic liberal tradition did, the notion of a constitutional democracy or a democracy governed by the rule of law, where the majority does not have the power to abridge the rights and liberties of minorities. This concept is very important nowadays with the powerful renaissance of the welfare state.

Finally, it sounds as a legitimate claim the one formulated by Hayek in the sense that, although the brand liberalism has been historically, and no doubt that in the future still will be, in the hands of those who properly defend an egalitarian approach to individual and collective questions, conceptually it is relevant to denounce this historical mistake; so that "Liberalism" and "liberals" should be used properly when describing those who consider that liberty is the most important political value and offer a coherent "theory of liberty".

[Recibido el 29 de mayo y aceptado el 21 de septiembre de 2009].

\section{BIBLIOGRAFÍA}

Ackerman, Bruce, We The People, I: Foundations (Cambridge, 1991).

BERLIN, Isaiah, Four Essays on Liberty (Oxford, 1969).

BobBio, Norberto, Left and Right: The significance of a Political Distinction (Chicago, 1997).

Burley, Justine, Introduction in Burley, Justine (ed.), Dworkin and His Critics (Massachusetts, 2004).

CARTER, Ian, The Independent Value of Freedom in Ethics 105 (1995).

Dworkin, Ronald, A Matter of Principle (Cambridge, 1985).

Dworkin, Ronald, Do Liberal Values Conflict? in LiLla, Mark - DworkIn, Ronald Silvers, Robert (eds.), The Legacy of Isaiah Berlin (New York, 2001).

Dworkin, Ronald, Do Liberty and Equality Conflict, in BARKer, Paul (ed.), Living as Equals (Oxford, 1996).

DwORKIN, Ronald, Sovereign Virtue: The Theory and Practice of Equality (Cambridge, 2000).

Dworkin, Ronald, Taking Rights Seriously (Cambridge, 1977).

DwORKIN, Ronald, Unenumerated Rights: Whether and How Roe Should Be Overruled, in The University of Chicago Law Review 59 (1992).

FINNIS, John, Is Natural Law Theory Compatible with Limited Government? in GEORGE, Robert (ed.), Natural Law, Liberalism and Morality (Oxford, 2002).

FINNIS, John, Kant v. Neo-Kantians, in Columbia Law Review 87 (1987). 
George, Robert, Making Men Moral: Civil Liberties and Public Morality (Oxford, 1993).

GraY, John, Isaiah Berlin (Princeton, 1996).

HAYEK, Friedrich, The Constitution of Liberty (Chicago, 1960).

NozicK, Robert, Anarchy, State and Utopia (New York, 1974).

Otsuka, Michael, Liberty, Equality, Envy and Abstraction, in Burley, in Burley, Justine (ed.) [véase].

POSNER, Richard, Frontiers of Legal Theory (Cambridge, 2001).

Posner, Richard, Overcoming Law (Cambridge, 1995).

Sunstein, Cass, Democracy and The Problem of Free Speech (New York, 1993). 

